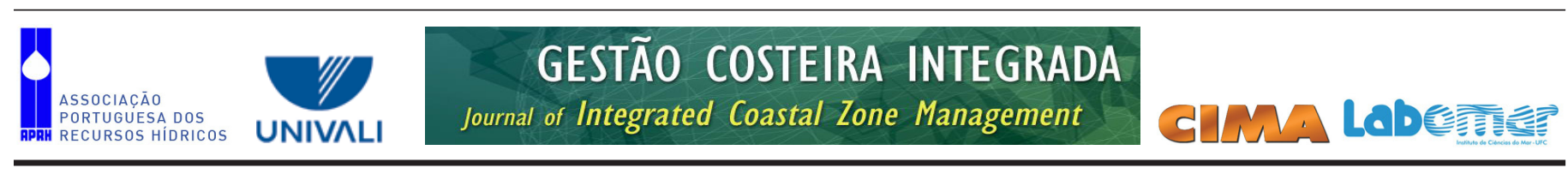

http://www.aprh.pt/rgci/pdf/rgci-395_Frias.pdf | DOI:10.5894/rgci395

\title{
Local marine litter survey - A case study in Alcobaça municipality, Portugal ${ }^{*}$
}

\author{
Levantamento de lixo marinho local - Um caso de estudo no \\ município de Alcobaça, Portugal
}

\author{
João P. G. L. Frias ${ }^{\circledR,}{ }^{1}$, Joana C. Antunes ${ }^{1}$, Paula Sobral ${ }^{1}$
}

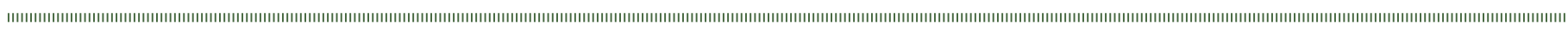

\begin{abstract}
Beach clean-ups campaigns organized by Coastwatch, Geota, are a common annually practice in the Portuguese coastal area. Bearing in mind the goals and objectives of the Marine Strategy Framework Directive (2008/56/EC) (MSFD), the Institute of Marine Research (IMAR FCT-UNL), in Faculty of Sciences and Technology of Universidade Nova de Lisboa participated for the first time in this project with the aim of collecting data about the state of coastal marine plastic pollution.

A close collaboration with Alcobaça municipality and with local teachers and students was set up, in order to gather information about marine plastic debris in this region. Three beaches were surveyed - Paredes de Vitória, Légua and Gralha - for number and mass (g) of plastic debris; and for concentrations of persistent organic pollutants (POP in $\mathrm{ng} \mathrm{g}^{-1}$ ) adsorbed to plastic pellets. Paredes de Vitória beach had highest number of items $(5200)$ and mass $(886 \mathrm{~g})$. No concerning concentrations of POP were found for Alcobaça municipality beaches, when compared with other beaches in Portugal and worldwide. White, aged and coloured pellets showed higher values of tDDT when compared to the data from 2009 and 2012, confirming the high persistence of this pesticide in the environment. Studies such as these are important, not only to gather information about stranded marine litter on the Portuguese coast, as a contribution to the goals Marine Strategy Framework Directive (MSFD), but also to promote environmentall awareness in society from young ages, on the issues of marine litter.
\end{abstract}

Keywords: microplastics, PAH, PCB, DDT, POP, PBTC, marine debris, Portugal.

\section{RESUMO}

As campanhas de limpeza de praia organizadas pelo Coastwatch - Geota, são prática comum anual na zona costeira portuguesa. Tendo presentes os objectivos da Directiva Quadro Estratégia Marinha (2008/56/EC) (DQEM), o Instituto do Mar, pólo da Faculdade de Ciências e Tecnologia da Universidade Nova de Lisboa (IMAR FCT-UNL) participou pela primeira vez neste projecto com o intuito de recolher informaçáo acerca do estado da poluição marinha costeira por plásticos. Uma colaboração através da Câmara Municipal de Alcobaça foi estabelecida com escolas do município, com o intuito de recolher informação acerca dos detritos plásticos marinhos nesta região. Foram investigadas três praias - Paredes de Vitória, Légua e Gralha quanto ao número e massa (g) de detritos; e quanto à concentração de poluentes orgânicos persistentes (POP em ng $g^{-1}$ ) adsorvidos às pastilhas de plástico (pellets). A praia de Paredes de Vitória foi aquela que apresentou um maior número de itens recolhidos (5200) e maior massa (886 g) das três praias amostradas. Não foram encontrados valores preocupantes de POP nas praias do município de Alcobaça, quando comparados com outras praias em Portugal e no mundo. Pellets brancos, envelhecidos e coloridos apresentam maiores valores de tDDT quando comparados com literatura de 2009 e 2012, confirmando a elevada persistência deste pesticida no ambiente. Estudos como este são importantes não apenas pela recolha de informação do estado de costa que reflecte a realidade do país, mas também pela possibilidade de fomentar uma consciencializaçấo ambiental na sociedade desde as camadas mais jovens, ao mesmo tempo que contribuem para a Directiva Quadro Estratégia Marinha (DQEM).

Palavras-chave: Microplásticos, PAH, PCB, DDT, POP, PBTC, detritos marinhos, Portugal.

@-Corresponding author: jpfrias@fct.unl.pt

1 - IMAR - Instituto do Mar, Departamento de Ciências e Engenharia do Ambiente, Faculdade de Ciências e Tecnologia da Universidade Nova de Lisboa, 2829-516 Caparica, Portugal.

* Submission: january 21, 2013; Evaluation: february 23, 2013; Reception of revised manuscript: march 8, 2013; Accepted: april 28, 2013; Available on-line: may 10, 2013. 


\section{INTRODUCTION}

Over the last few decades, several studies have documented numerous impacts associated with plastic marine debris in coastal and marine environments (Derraik, 2002; Thompson et al., 2004; Ogata et al., 2009; Moore et al., 2001a, 2001b and 2008), resulting from excessive consumption of this type of materials (PlasticsEurope, 2012) and inappropriate disposal of plastic products used in daily life (Andrady, 2011). In order to raise awareness and take action towards a 'good environmental status', in Europe, the Marine Strategy Framework Directive (2008/56/EC) (MSFD) was created with specific goals to be achieved by 2020 (Galgani et al., 2010). One of the descriptors of the MSFD is marine litter to which European countries are gathering data from beach and ocean surveys.

Floating plastic debris have been reported in the world's oceans since the early 1970's with the amount of debris showing a documented exponential increase into the early 1990's and in the 2000's (Law et al., 2010). Currently there is an on-going debate on either plastic debris concentrations in the oceans are increasing or stabilizing (Corcoran et al., 2009, Cole et al., 2011).

The main impacts associated with plastic debris pollution in marine environments, are (1) the accumulation of debris on shore (Laist, 1987; Martins \& Sobral 2011); (2) particle uptake and ingestion by marine organisms (Crimmins et al., 2002; Browne et al., 2008); (3) entanglement of marine animals such as fish, mammals, turtles and birds (Furness, 1983; Laist, 1997; Vlieststra \& Parga, 2002, Franeker et al. 2011) and (4) the capacity to adsorb persistent bioaccumulative and toxic chemicals (PBTC), (Mato et al. 2001, Takada et al., 2005; Teuten et al., 2007; Ogata et al., 2009; Frias et al., 2010; Heskett et al., 2012).

Recently, studies focused on microplastic particles and their potential effects on food webs (Gregory \& Andrady, 2003; Bodin et al. 2007; Andrady, 2011), and the capacity for filter feeders to ingest plastic particles (Crimmins et al., 2002; Browne et al., 2008).

Plastics and microplastics (diameter $<5 \mathrm{~mm}$ ) (Barnes et al., 2009), are widely dispersed in the open ocean due to their low density and ability to float, which enables them to travel great distances from their source, and accumulate in gyres due to ocean circulation (Pichel et al., 2007). Photochemical degradation induces plastic fragmentation into smaller particles which will have the previously described effects on food webs (Barnes et al., 2009). Denser varieties of plastics such as nylons or polyethylene terephthalate (PET) tend to sink in the water column and reach the coastal sediment (Andrady, 2011). On beaches, plastic fragments are derived either (1) from inland sources and are transported to coasts by water courses, wind, drainage systems, sewage overflows or human activity, or (2) directly from the oceans where low density floating varieties accumulateand are transported across great distances. According to the Joint Group of Experts on the Scientific Aspects of Marine Pollution (GESAMP) eighty per cent of marine debris result from inland sources (1) and twenty per cent result from oceans (2) (Bowmer \& Kershaw, 2010). The high incidence of plastic marine debris reported worldwide (Moore et al., 2001a, 2001b, 2002; Thiel et al.,
2003; Ivar do Sul et al., 2007; Moore, 2008; Costa et al., 2010; Frias et al., 2010; Martins \& Sobral, 2011), have been of extreme importance in marine (Derraik, 2002; Page \& McKenzie, 2004; Arthur et al., 2008) and in social sciences research (Thiel et al. 2003, Bravo et al., 2009, Hinojosa \& Thiel, 2009, Luís \& Spinola, 2010).

The Portuguese coastal area is also extremely vulnerable to plastic accumulation on beaches not only from land sources (river discharges and population concentration along the coast), but also from the sea, as the country is an important route for commercial vessels and cruise ships (Martins \& Sobral, 2011). Previous studies in Portugal (5 beaches) show average plastic debris densities ranging from 28.6 to 392.8 items $\mathrm{m}^{-2}$ (Martins \& Sobral, 2011) and accumulation of POP in plastic pellets with PAHs concentrations of plastic pellets ranging from 0.2 to $319.2 \mathrm{ng} \mathrm{g}^{-1}$, PCBs from 0.02 to $15.56 \mathrm{ng} \mathrm{g}^{-1}$ and DDTs from 0.16 to $4.05 \mathrm{ng} \mathrm{g}^{-1}$ (Frias et al., 2010).

An on-going project untitled 'Microplastics and persistent pollutants - a double threat to marine life - POIZON' (PTDC/MAR/102677/2008) is being conducted, which the main goals are (a) monitoring microplastics in the Portuguese coast, (b) identifying the physical mechanisms of plastic degradation and (c) understanding the effects of plastic and contaminants in ocean food-chains caused by ingestion.

With this set of goals in mind, the aim of this study is to conduct identification and characterization of marine debris collected within the scope of Coastwatch -Geota project in beaches of Alcobaça municipality and at the same time raise awareness in youth as a way to change society in the forthcoming decades. Data is integrated into the POIZON project, which provides relevant information about plastic debris pollution in Portugal, according to the descriptor 10 of the MSFD - 'marine litter'.

\section{METHODS AND MATERIALS}

Marine debris samples were collected between January and February of 2012, in three beaches in Alcobaça municipality (Figure 1), Paredes de Vitória (PV) $\left(39^{\circ} 42^{\prime} 10.2^{\prime \prime} \mathrm{N}\right.$, $\left.9^{\circ} 2^{\prime} 59.7^{\prime \prime} \mathrm{W}\right)$; Légua (L) (39 39'1.11"N, 9०4'14.4”W) and Gralha (G) $\left(39^{\circ} 31^{\prime} 34.63^{\prime \prime} \mathrm{N}, 9^{\circ} 7^{\prime} 49.47^{\prime \prime} \mathrm{W}\right)$, by the team from IMAR FCT-UNL and local high school students (ages ranging from 16 to 19 years old). Coastwatch- Geota has been conducting beach surveys of marine debris for 22 years in Portugal, and has several partnerships with nongovernmental organizations (NGO), municipalities and schools, where volunteers participate, contribute and learn how to preserve coastal areas. Volunteer high school students from 5 classes ( -20 students each) of Benedita's high school and teachers participated in an outreach and education awareness workshop and clean-up surveys, contributing to the data gathered in this work.

Beaches were chosen according to selection criteria such as accessibility, orientation of dominant north-western winds (northerly wind exposure) and proximity to industrial activities. All samples were collected during equinoctial spring tides in order to maximize the probability of debris accumulation. Quadrat areas were randomly set along $1 \mathrm{~km}$ in the last high tide mark and top $2 \mathrm{~cm}$ of sand was 


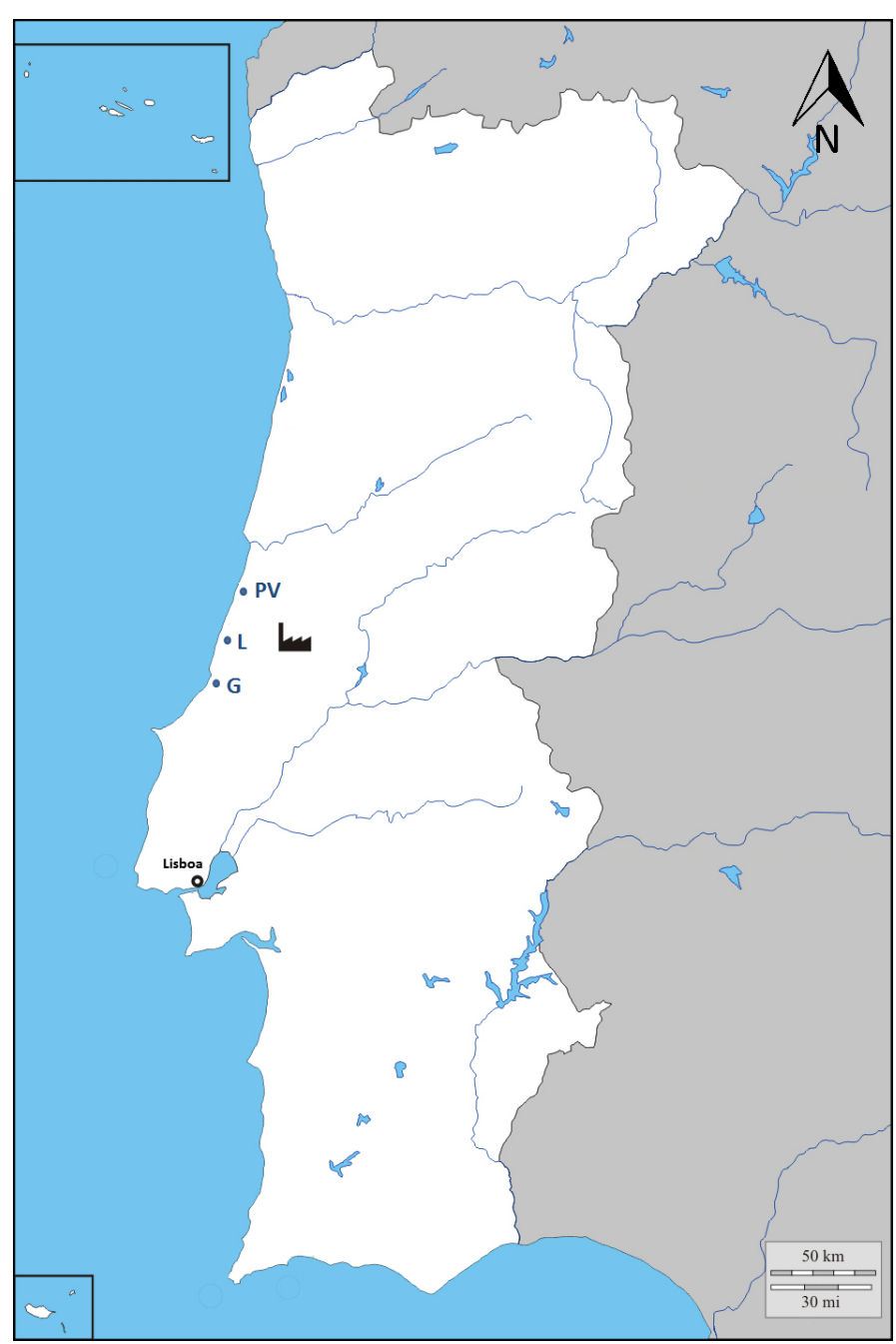

Figure 1. Sampled beaches in Portuguese coast: PV - Paredes de Vitória, L - Légua, G- Gralha.

Figura 1. Praias amostradas na costa Portuguesa: PV - Paredes de Vitória, L-Légua, G-Gralha.

scooped or sieved into paper bags in order to collect debris. Triplicates were collected in two scenarios: (A) $0.5 \times 0.5$ $\mathrm{m}$ areas (content not sieved and placed directly into paper bags) and (B) $2 \times 2 \mathrm{~m}$ areas (sieved in situ for debris using a commercial $2.5 \times 3.5 \mathrm{~mm}$ metal mesh size).

Samples were then transported to the laboratory where quadrats from $\mathrm{A}$ areas were introduced into a glass tank with a concentrated solution of sodium chloride $(\mathrm{NaCl})(140$ $\left.\mathrm{g} \mathrm{L}^{-1}\right)$, stirred vigorously and the floating plastic particles recovered. This procedure was repeated several times until no particles could be seen on the sediment. The water was then filtered with a GAST vacuum pump, onto Whatman GF/C filters $(-1 \mu \mathrm{m}$ pore size and $47 \mathrm{~mm}$ diameter) to recover any plastic pieces of minor dimensions, not visually identified in the solution. Samples from B areas were separated by type of debris. All plastic pieces collected were classified, counted and weighted, according to an adaptation from the size classes adopted by Ogi \& Fukumoto (2000) and OSPAR methodologies (corresponding to classes 11 and 12): class 1 $(\leq 1 \mathrm{~mm})$, class $2(>1 \mathrm{~mm}$ and $\leq 2 \mathrm{~mm})$, class $3(>2 \mathrm{~mm}$ and $\leq 3 \mathrm{~mm})$, class $4(>3 \mathrm{~mm}$ and $\leq 4 \mathrm{~mm})$, class 5 ( $>4 \mathrm{~mm}$ and $\leq 5 \mathrm{~mm})$, class 6 ( $>5 \mathrm{~mm}$ and $\leq 6 \mathrm{~mm})$, class 7 ( $>6 \mathrm{~mm}$ and $\leq 7 \mathrm{~mm})$, class $8(>7 \mathrm{~mm}$ and $\leq 8 \mathrm{~mm})$, class $9(>8 \mathrm{~mm}$ and $\leq 9$ $\mathrm{mm})$, class 10 ( $>9 \mathrm{~mm}$ and $\leq 10 \mathrm{~mm})$, class $11(>1 \mathrm{~cm} \mathrm{e} \leq 2,5$ $\mathrm{cm})$ and class $12(>2,5 \mathrm{~cm})$, and kept in covered glass Petri dishes until analysis of PAH, PCB and DDT. All materials used in the experiment, both in situ and in laboratory were either paper or glass, to avoid contaminations.

Regarding POP analysis, due to technical limitations such as weight needed to conduct the analysis $(-2 \mathrm{~g}$ of pellets per beach), a composite sample with all polymer types from the three beaches was made and POP concentrations in pellets was estimated for the region. Resin pellets were separated from the remaining marine debris and further categorized in four classes (white, aged, colored and black) according to a classification adapted from Endo et al., 2005, in which aged pellets correspond to discolored yellow-brown pellets which have spent some time in the oceans and white pellets are translucent white virgin pellets. Coloured pellets included pellets with pigments and the black pellets class was created due to its different composition, later identified as polyurethane (PU).

For PAH analysis, each pellet class were spiked with $1 \mathrm{ml}$ surrogate standards (SUPELCO) containing acenapththene-d10 $\left(0.408 \mu \mathrm{g} \mathrm{m} \mathrm{m}^{-1}\right)$, phenanthrene-d 10 $\left(0.397 \mu \mathrm{g} \mathrm{ml}^{-1}\right)$, chrysene-d $12\left(0.397 \mu \mathrm{g} \mathrm{ml}^{-1}\right)$, perylene-d12 $\left(0.433 \mu \mathrm{g} \mathrm{ml}^{-1}\right)$. The extraction was made in an accelerated solvent extractor Dionex ${ }^{\oplus}$ ASE 200 with a mixture of hexane:acetone $(1: 1, \mathrm{v}: \mathrm{v})$ at $100^{\circ} \mathrm{C}$ e 1500 psi for 5 minutes, followed by static extraction for 5 minutes. The extract was fractioned with a silica:alumina $(1: 1)$, glass column. The first fraction, corresponding to aliphatic hydrocarbons, was eluted with $20 \mathrm{ml}$ of $\mathrm{n}$-hexane and not analysed. The second fraction, containing the PAH compounds, were collected by eluting $30 \mathrm{ml}$ of $\mathrm{n}$-hexane/dichloromethaneromethane (9:1, v:v) and $40 \mathrm{ml} \mathrm{n}$-hexane/dichloromethane (4:1, v:v). The solvent was evaporated by a rotator evaporator and concentrated to $0.5 \mathrm{ml}$ under a gentle stream of $\mathrm{N} 2$ for prior analysis. The determination of PAHs was performed on a Thermo ${ }^{\circ}$ DSQ Trace GC Ultra gas chromatography- mass spectrometry (GC-MS) system with a $30 \mathrm{~m} \mathrm{x} 0.25 \mathrm{~mm}$ x $0.25 \mu \mathrm{m}$ film thickness with capilar column J\&W, DB5mn (Argilent, USA) in selected ion monitoring mode (SIM), (Martins, 2012). Injection was performed by autosampler in the splitless mode, at $280^{\circ} \mathrm{C}$ and, interface line and ion source temperature maintained at $220^{\circ} \mathrm{C}$. Helium was used as carrier gas at a flow of $1.0 \mathrm{ml} . \mathrm{min}-1$. Initial oven temperature was $70^{\circ} \mathrm{C}$, then ramped to $140{ }^{\circ} \mathrm{C}$ at $30^{\circ} \mathrm{C}$ min-1, followed by another ramp step to $270{ }^{\circ} \mathrm{C}$ at a rate of 3 o C min-1, and held for $15 \mathrm{~min}$. Relevant standards were run to check column performance, peak height and resolution, before analysis. Concentrations of these individual PAHS was done by the internal standard peaks area method, ion ratio $(\mathrm{m} / \mathrm{z})$ of a standard PAH solution NIST (SRM 2260a) and using two calibration curves with nine points each, for each compound ranging 0.1-0.7 ng g-1 (dry weight basis) (Martins et al., 2008). With each set of samples to be analysed, a solvent blank, a standard mixture and a procedural blank were run in sequence to check for 
contamination, peak identification and quantification. Seventeen individual PAHs were analysed: acenaphthylene (ANY), acenaphthene (ANA), fluorene (F), phenantrene (P), anthracene (A) (three-ring compounds), fluoranthene (FL), pyrene (PY), benzo(a)anthracene (BA), chrysene (C) (four rings), benzo(b)fluoranthene $(\mathrm{BBF})$, benzo(k)fluoranthene (BKF), benzon(a)pyrene (BAP), benzo(e)pyrene (BEP), dibenzo(ah)anthracene (DBA), perylene (Per) (five rings), indeno(1,2,3-cd)pyrene (IN) and benzo(g,h,i)perylene (BPE) (six rings). Concentrations of these individual PAHS was done by the internal standard peaks area method, ion ratio $(\mathrm{m} / \mathrm{z}$ ) of a standard PAH solution NIST (SRM 2260a) and using two calibration curves with nine points each, for each compound ranging 0.1-0.7 $\mathrm{ng} \mathrm{g}^{-1}$ (dry weight basis). With each set of samples to be analysed, a solvent blank, a standard mixture and a procedural blank were run in sequence to check for contamination, peak identification and quantification.

For PCB determination, pellet organochlorines were Soxhlet extracted with hexane for seventeen hours. The extraction was fractioned with a Florisil glass column, and then eluted with $n$-hexane, followed by a clean-up with sulphuric acid $\left(\mathrm{H}_{2} \mathrm{SO}_{4}\right)$. The extracts were then injected in a Hewlett Packard chromatographer (ECD), model 6890 with capilar column J\&W, DB5 $(60 \mathrm{~m})$ and automatic sampler. Eighteen PCB congeners were analysed:
CB18 (2,2',5-trichlorobiphenyl),
CB26 (2,3',5-trichlorobiphenyl),
CB31 (2,4',5-trichlorobiphenyl),
CB44 (2,2',3,5'-tetrachlorobiphenyl),
CB49 (2,2', 4, ', -tetrachlorobiphenyl),
CB52 (2,2',5,5'-tetrachlorobiphenyl),
CB101 (2,2',4,5,5'-pentachlorobiphenyl),
CB105 (2,3,3',4,4'-pentachlorobiphenyl),
CB118 (2,3',4,4',5-pentachlorobiphenyl),
CB128 (2,2',3,3',4,4'-hexachlorobiphenyl),
CB138 (2, 2',3,4,4', ','-hexachlorobiphenyl),
CB149 (2,2',3,4', 5',6-hexachlorobiphenyl),
CB151 (2,2',3,5, 5',6-hexachlorobiphenyl),
CB153 (2,2',4, ', , 5, 5'-hexachlorobiphenyl),
CB170 (2,2',3,3',4,4',5-Heptachlorobiphenyl),
CB180 (2,2',3,4,4', 5, 5'-Heptachlorobiphenyl),
CB187 (2,2',3,4', , , ,',6-heptaclorobiphenyl) and
CB194 (2,2',3,3',4,4',5, 5'-Octachlorobiphenyl).

Following the procedure for PCB analysis, a second extraction was made to determine the DDEs, DDDs and DDTs concentrations in samples, due to the fact that its results may be affected by PCB concentrations. Concentrations of different congeners were determined using a standard solution and the internal standard peaks area method with two calibration curves with seven points each. The detection limit for these compounds is $0.01 \mathrm{ng}^{-1} \mathrm{~g}^{-1}$ (dry weight basis) (Ferreira \& Vale, 2001). Same procedure was conducted for DDT concentrations.

\section{RESULTS}

In order for participants to feel part of the final goal of the beach clean-up campaign, awareness raising workshops and beach clean-ups surveys were conducted with approximately 115 people from 5 classes of Benedita's high school. Due to the previous workshop, methodologies were easily adopted on site, following safety precautions such as wearing gloves and reporting dead animals, while working in groups to collect marine debris. Feedback from students and teachers was positive, as the goals for collecting marine debris were clearly understood.

A total amount of 5297 plastic items $(-906 \mathrm{~g})$, was collected with an average density of $3126 \mathrm{~m}^{2}$ (average weight of $452 \mathrm{~g} \mathrm{~m}^{-2}$ ) from three beaches. Plastic abundance is higher for classes 3, 4 and $5 \mathrm{~mm}$ in diameter (Figure 2), representing $67 \%$ of total abundance, which is consistent with previous results (Martins \& Sobral, 2011). Figure 3 shows the weight of the size classes and, as expected classes with higher size have higher mass, namely $1 \mathrm{~mm}$ to $2.5 \mathrm{~cm}$ and $>2.5 \mathrm{~cm}$.

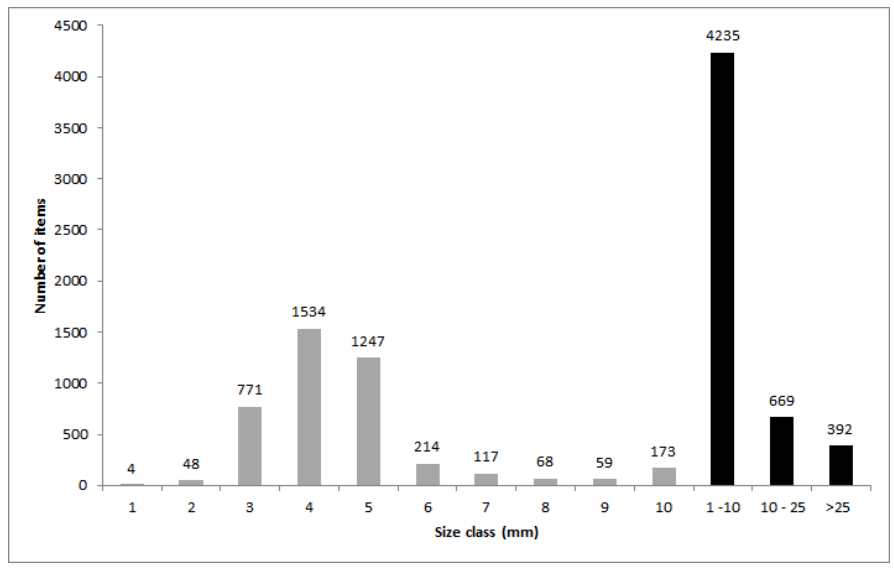

Figure 2. Total number of collected plastic debris by size class ( $\mathrm{mm})$. Figura 2. Número total de detritos plásticos recolhidos por classe de tamanho ( $\mathrm{mm}$ ).

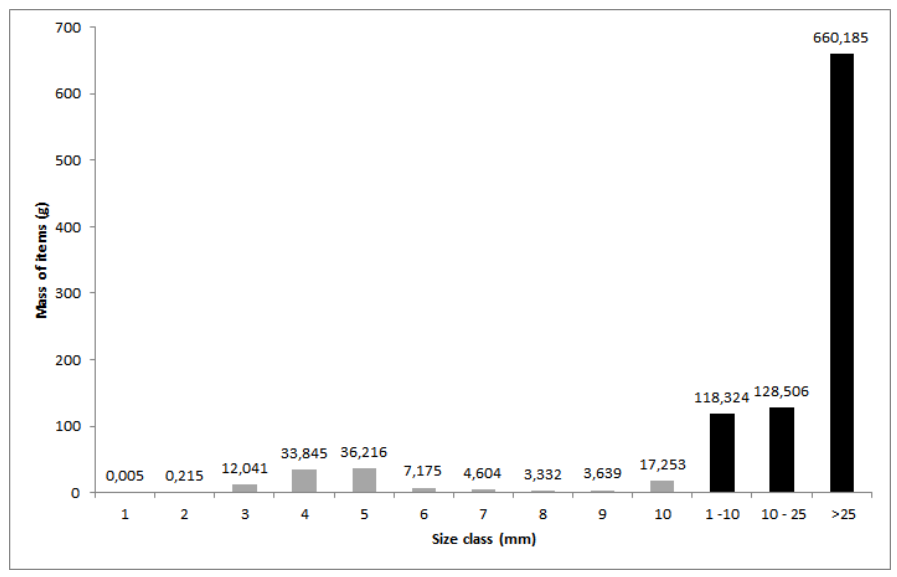

Figure 3. Total mass (g) of collected plastic debris by size class ( $\mathrm{mm}$ ). Figura 3. Massa (g) total de detritos plásticos recolhidos por classe de tamanho $(\mathrm{mm})$. 
Microplastics $(<5 \mathrm{~mm})$ represent $68 \%$ of all collected plastics. Results were divided by square areas and Table 1 represents data collected by type of material and beach for (A) $50 \times 50 \mathrm{~cm}$ square areas and Table 2 represents data for (B) $2 \times 2 \mathrm{~m}$ square areas. In PV beach, more plastic debris items were collected than in any other beach in this study. Tables 1 and 2 were used to estimate average number and mass (g) of items $\mathrm{m}^{-2}$ in the three beaches (Table 3). Results show relatively high values for PV with 3060 plastic items $\mathrm{m}^{-2}$.

Table $1.50 \times 50 \mathrm{~cm}$ quadrats data by type of material and beach.

Tabela $1.50 \times 50 \mathrm{~cm}$ data by type of material and beach.

\begin{tabular}{|c|c|c|c|c|}
\hline $50 \times 50$ & Type of material/ beach & Paredes de Vitória beach & Légua beach & Gralha beach \\
\hline \multirow{6}{*}{$\begin{array}{l}\text { Number of } \\
\text { items }\end{array}$} & Pellets & 2217 & 36 & 1 \\
\hline & Fragments & 836 & 7 & 0 \\
\hline & Styrofoam & 136 & 21 & 0 \\
\hline & Sponge & 12 & 1 & 0 \\
\hline & Fibre & 2 & 2 & 1 \\
\hline & TOTAL & 3203 & 67 & 2 \\
\hline \multirow{6}{*}{ Mass (g) } & Pellets & 53.98 & 0.97 & 0.02 \\
\hline & Fragments & 348.62 & 0.32 & 0.00 \\
\hline & Styrofoam & 1.29 & 0.02 & 0.00 \\
\hline & Sponge & 2.52 & 0.00 & 0.00 \\
\hline & Fibre & 0.02 & 0.00 & 0.95 \\
\hline & TOTAL & 406.42 & 1.32 & 0.97 \\
\hline
\end{tabular}

Table $2.2 \times 2$ m quadrats data by type of material and beach.

Tabela 2. $2 \times 2 \mathrm{~m}$ data by type of material and beach.

\begin{tabular}{|c|c|c|c|c|}
\hline $2 \times 2$ & Type of material/ beach & Paredes de Vitória beach & Légua beach & Gralha beach \\
\hline \multirow{7}{*}{$\begin{array}{l}\text { Number of } \\
\text { items }\end{array}$} & Pellets & 1213 & 0 & 2 \\
\hline & Fragments & 713 & 0 & 9 \\
\hline & Styrofoam & 58 & 0 & 9 \\
\hline & Sponge & 4 & 0 & 1 \\
\hline & Fibre & 8 & 0 & 7 \\
\hline & Textiles & 1 & 0 & 0 \\
\hline & TOTAL & 1997 & 0 & 28 \\
\hline \multirow{7}{*}{ Mass (g) } & Pellets & 30.17 & 0.00 & 0.05 \\
\hline & Fragments & 397.35 & 0.00 & 11.87 \\
\hline & Styrofoam & 0.28 & 0.00 & 0.91 \\
\hline & Sponge & 0.09 & 0.00 & 0.14 \\
\hline & Fibre & 39.55 & 0.00 & 4.62 \\
\hline & Textiles & 12.30 & 0.00 & 0.00 \\
\hline & TOTAL & 479.73 & 0.00 & 17.60 \\
\hline
\end{tabular}


Table 3. Average number and mass (g) by beach $(\mathrm{m} 2)$.

Tabela 3. Número e massa (g) médios por praia (m2).

\begin{tabular}{cccccccc}
\hline${\text { Average number of items by } \mathbf{~}^{2}}^{2}$ & Pellets & Fragments & Styrofoam & Sponge & Fibre & Textile & TOTAL \\
\hline Paredes de Vitória beach & 2076.85 & 847.05 & 123.30 & 10.60 & 3.60 & 0.25 & $\mathbf{3 0 6 1 . 6 5}$ \\
\hline Légua beach & 28.80 & 5.60 & 16.80 & 0.80 & 1.60 & 0.00 & $\mathbf{5 3 . 6 0}$ \\
\hline Gralha beach & 4.17 & 0.75 & 0.75 & 0.08 & 4.58 & 0.00 & $\mathbf{1 0 . 3 3}$ \\
\hline Average mass by $\mathbf{m}^{2}$ & Pellets & Fragments & Styrofoam & Sponge & Fibre & Textile & TOTAL \\
\hline Paredes de Vitória beach & 50.72 & 378.23 & 1.10 & 2.03 & 9.90 & 3.08 & $\mathbf{4 4 5 . 0 7}$ \\
\hline Légua beach & 0.79 & 0.45 & 0.01 & 0.00 & 0.60 & 0.00 & $\mathbf{1 . 8 6}$ \\
\hline Gralha beach & 0.08 & 0.99 & 0.08 & 0.01 & 4.18 & 0.00 & $\mathbf{5 . 3 3}$ \\
\hline
\end{tabular}

Regarding POP analysis, a composite sample with all polymer types was made to estimate adsorbed concentrations in pellets. The selection criteria for this is related to the minimum amount of pellets needed $(\sim 2 \mathrm{~g})$ to conduct the analysis. Tables 4 and 5 present data of PAH, PCB and DDT concentrations, respectively.

Table 4. Polycyclic aromatic hydrocarbons data by colour (ng g-1).

Tabela 4. Concentraçôes de hidrocarbonetos policíclicos aromáticos por cor (ng g-1).

\begin{tabular}{|c|c|c|c|c|c|c|}
\hline & & & & & lcobaça & \\
\hline & & & white & aged & colour & black \\
\hline & acenaphthylene & ANY & 0.91 & 19 & 0.89 & 2.6 \\
\hline & acenaphthene & ANA & 10 & 11 & 11 & 5.6 \\
\hline Compounds with & fluorine & $\mathbf{F}$ & 3.7 & 7.0 & 8.0 & 9.2 \\
\hline & phenantrene & $\mathbf{P}$ & 18 & 32 & 38 & 35 \\
\hline & anthracene & A & $<0.3$ & $<0.3$ & $<0.3$ & $<0.3$ \\
\hline & fluoranthene & FL & 11 & 14 & 51 & 38 \\
\hline Compounds with & pyrene & PY & 17 & 13 & 30 & 59 \\
\hline 4 aromatic rings & benzo(a)anthracene & BA & $<0.4$ & 2.8 & 2.0 & $<0.4$ \\
\hline & chrysene & C & 9.8 & 18 & 8.8 & 19 \\
\hline & benzo(b)fluoranthene & BBF & $<0.8$ & $<0.8$ & 2.2 & 7.6 \\
\hline & benzo(k)fluoranthene & BKF & $<0.5$ & 4.1 & 3.4 & 3.4 \\
\hline Compounds with & benzo(e)pyrene & BEP & $<0.4$ & 223 & 84 & 60 \\
\hline 5 aromatic rings & benzo(a)pyrene & $\mathrm{BaP}$ & $<0.6$ & 3.7 & $<0.6$ & 4.8 \\
\hline & perylene & Per & $<0.3$ & $<0.3$ & $<0.3$ & $<0.3$ \\
\hline & dibenzo(ah)anthracene & DBA & $<0.5$ & $<0.5$ & $<0.5$ & $<0.5$ \\
\hline Compounds with & indeno(1.2.3-cd)pyrene & IN & $<0.5$ & $<0.5$ & 4.3 & 19 \\
\hline 6 aromatic rings & benzo $(\mathrm{g}-\mathrm{i})$ perylene & BPE & $<0.7$ & $<0.7$ & 2.9 & 51 \\
\hline & & tPAH & 70 & 348 & 246 & 315 \\
\hline
\end{tabular}


Table 5. Polychlorinated biphenyls and DDT data by colour (ng g-1). Tabela 5. Concentraçóes de bifenis policlorados e DDT por cor (ng g-1).

\begin{tabular}{|c|c|c|c|c|}
\hline & \multicolumn{4}{|c|}{ Alcobaça } \\
\hline & white & aged & colour & black \\
\hline CB018 & 0.05 & $<0.01$ & 0.06 & $<0.01$ \\
\hline CB26 & $<0.01$ & $<0.01$ & $<0.01$ & $<0.01$ \\
\hline CB31 & 0.30 & 0.17 & 0.56 & 0.28 \\
\hline CB44 & $<0.01$ & 0.04 & $<0.01$ & $<0.01$ \\
\hline CB49 & $<0.01$ & $<0.01$ & $<0.01$ & $<0.01$ \\
\hline CB52 & 0.17 & 0.07 & 0.23 & 0.21 \\
\hline CB101 & $<0.01$ & 0.11 & $<0.01$ & 0.47 \\
\hline CB105 & $<0.01$ & 0.46 & $<0.01$ & $<0.01$ \\
\hline CB118 & $<0.01$ & $<0.01$ & 0.13 & $<0.01$ \\
\hline CB128 & 0.04 & 0.03 & $<0.01$ & $<0.01$ \\
\hline CB138 & $<0.01$ & 1.42 & $<0.01$ & 0.03 \\
\hline CB149 & 1.00 & 1.64 & 1.07 & 1.34 \\
\hline CB151 & $<0.01$ & 0.33 & 0.21 & 0.48 \\
\hline CB153 & 1.10 & 0.92 & 1.40 & 1.80 \\
\hline CB170 & 0.10 & $<0.01$ & $<0.01$ & 0.21 \\
\hline CB180 & $<0.01$ & 1.02 & 0.71 & 1.82 \\
\hline CB187 & $<0.01$ & 1.69 & 0.66 & $<0.01$ \\
\hline CB194 & $<0.01$ & $<0.01$ & $<0.01$ & 1.72 \\
\hline tPCB & 2.8 & 7.9 & 5 & 8.3 \\
\hline DDE & 0.27 & 0.38 & 1.20 & 0.34 \\
\hline DDD & 0.3 & 0.35 & 0.32 & 1.08 \\
\hline DDT & 1.7 & 1.8 & 0.62 & $<0.01$ \\
\hline tDDT & 2.3 & 2.5 & 2.1 & 1.4 \\
\hline
\end{tabular}

Figure 4 shows $\mathrm{PAH}$ adsorbed concentrations where white pellets $\left(18 \mathrm{ng} \mathrm{g}^{-1}\right)$ had higher concentration of phenantrene (P) and aged (223 $\left.\mathrm{ng} \mathrm{g}^{-1}\right)$, coloured $\left(84 \mathrm{ng} \mathrm{g}^{-1}\right)$ and black (60 $\left.n \mathrm{ng}^{-1}\right)$ pellets presented higher concentrations of benzo(a) pyrene $(\mathrm{BaP})$.

Figure 5 shows how that white and coloured pellets had higher concentrations for the PCB congener 153 (1.1 and $1.4 \mathrm{ng} \mathrm{g}^{-1}$, respectively), black pellets for PCB 180 (1.82 ng $\left.\mathrm{g}^{-1}\right)$ and aged pellets for PCB $187\left(1.69 \mathrm{ng} \mathrm{g}^{-1}\right)$. Adsorbed concentrations of pesticides such as DDE, DDD and DDT are presented in figure 6 . Coloured pellets had higher concentrations for DDE $\left(1.2 \mathrm{ng} \mathrm{g}^{-1}\right)$, black pellets for DDD $\left(1.08 \mathrm{ng} \mathrm{g}^{-1}\right)$, and white $\left(1.7 \mathrm{ng} \mathrm{g}^{-1}\right)$ and aged pellets $(1.8 \mathrm{ng}$ $\left.\mathrm{g}^{-1}\right)$ for DDT. Total PAH, PCB and DDT concentrations are shown in figure 7 and 8.

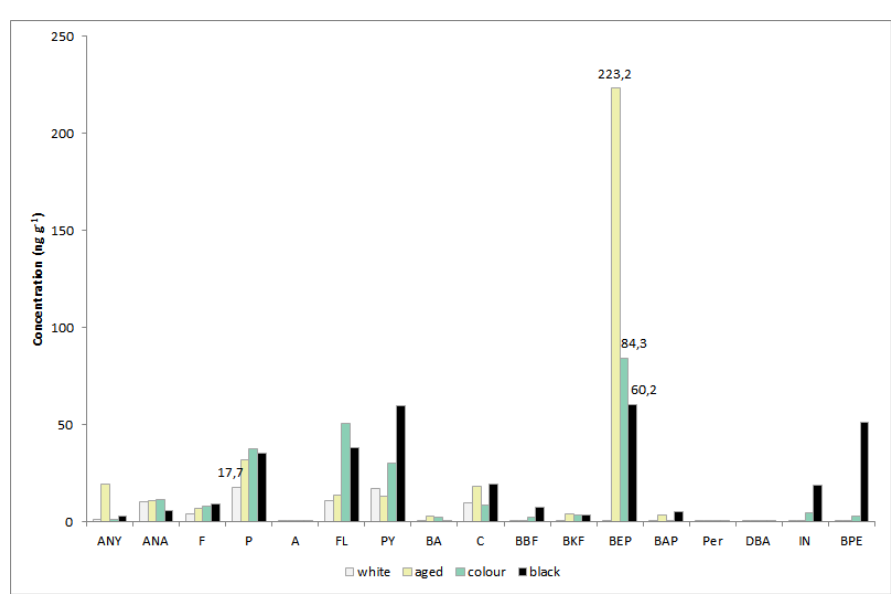

Figure 4. PAH concentrations (ng g-1) in each pellet category.

Figura 4. Concentraçóes de PAH (ng g-1) em cada categoria de pellets.

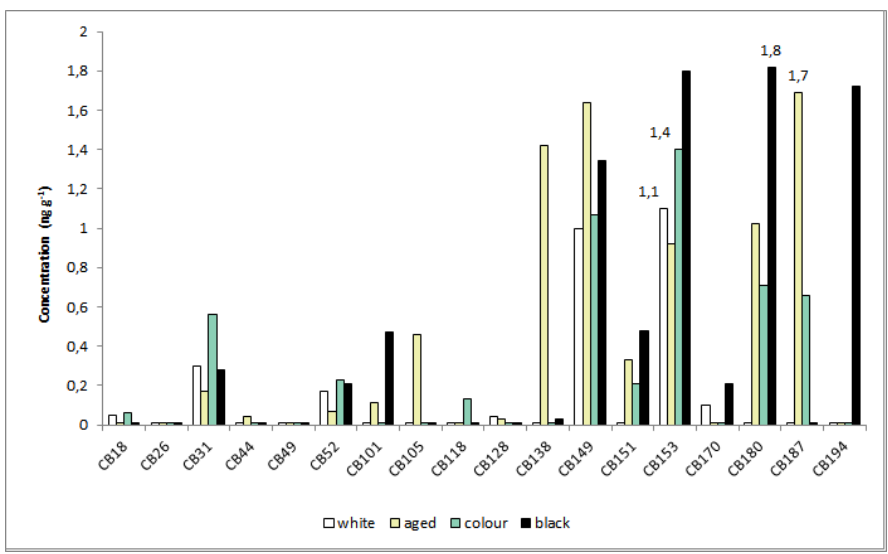

Figure 5. PCB congeners concentrations (ng g-1) in each pellet category.

Figura 5. Concentraçóes de congénros de PCB (ng g-1) em cada categoria de pellets.

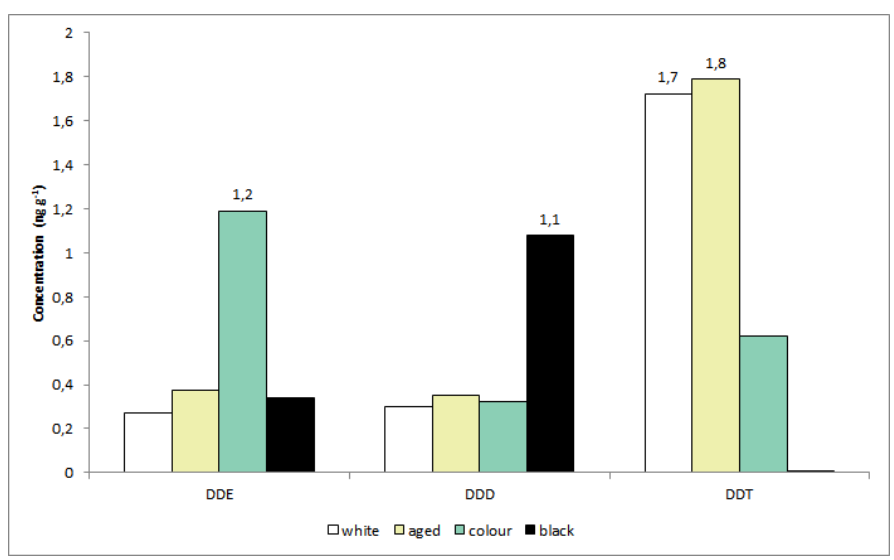

Figure 6. DDE, DDD and DDT concentrations (ng g-1) in each pellet category.

Figura 6. Concentraçóes de DDE, DDD e DDT (ng g-1) em cada categoria de pellets. 


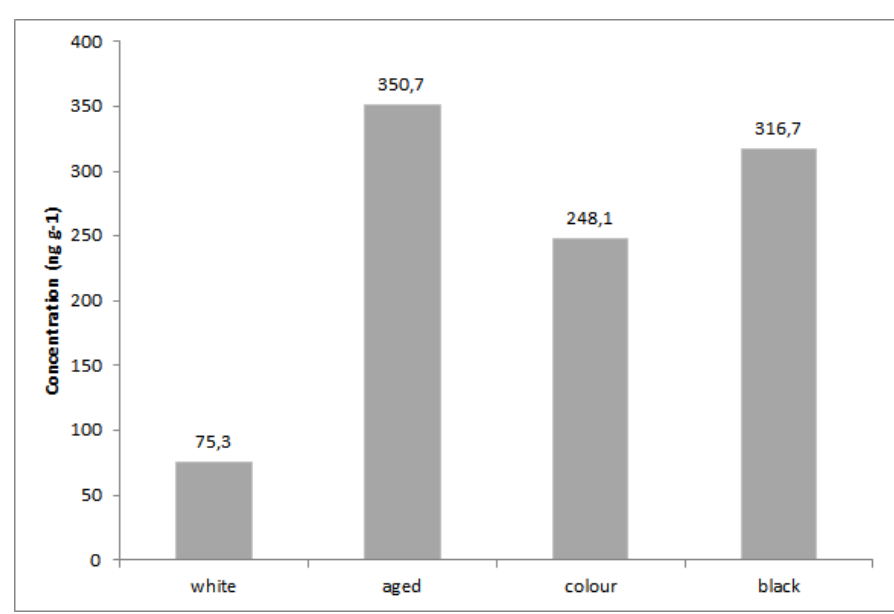

Figure 7. $\mathrm{tPAH}$ concentrations (ng g-1) in each pellet category. Figura 7. Concentraçóes de tPAH (ng g-1) em cada categoria de pellets.

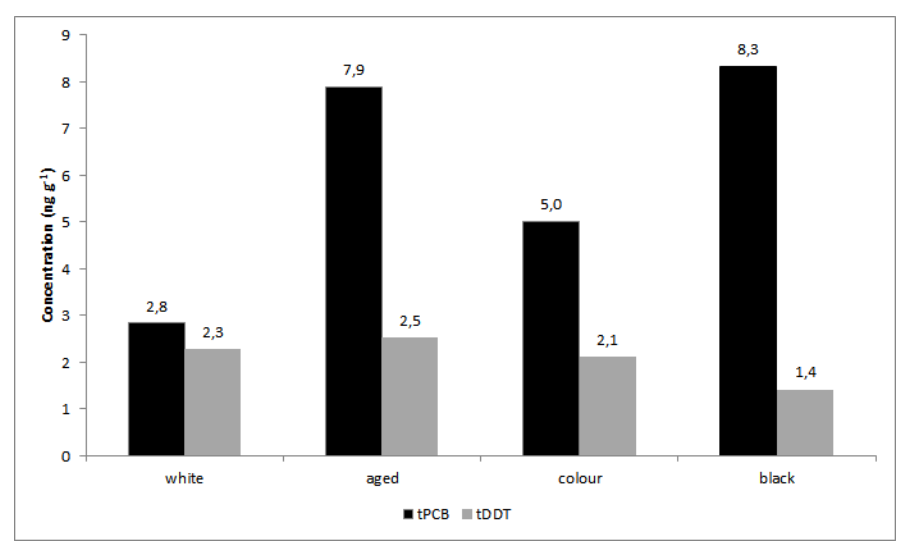

Figure 8. $\mathrm{tPCB}$ and tDDT concentrations (ng g-1) in each pellet category.

Figura 8. Concentraçóes de tPCB e tDDT (ng g-1) em cada categoria de pellets.

\section{DISCUSSION}

Stranded marine debris abundance is mainly correlated to physical factors - distance to sources, litter form, physiography and orientation of beach. Regarding abiotic factors, the most important are wind direction, surface currents and waves (Debrot et al., 1999). Through the collaboration established for this work, it was possible to gather data from a coastal region where several plastic packaging production facilities are located.

Education, outreach and awareness of plastic marine debris on beaches were possible through interactive workshops and beach clean-ups with approximately 115 people. Data is valuable as it can be used to estimate realistic scenarios of accumulation of plastic debris and contaminant adsorptions in pellets.
For $\mathrm{G}$ beach, a protected area in Alcobaça municipality, there was an assumption that densities of plastic marine debris were not high, and these results were confirmed, as shown in Tables 1 and 2. The highest amount of plastic debris, both in number and in weight was found at PV beach. A river stream that flows directly to this beach, and drains from several plastic industries and localities may have contributed to increase the number of plastic marine debris collected.

It is important to have into consideration that data was collected during equinoctial high tides and that extreme events have high influence on the amount of marine debris collected on shore. Values for PV beach are not expected on a monthly basis, as the coastal area is a dynamic system and variability of stranded marine debris is high, therefore it is advisable to conduct a monitoring plan using the same methodology in order to assess seasonal fluctuations.

To compare our PBTC concentration results with results worldwide, total concentrations of each group of contaminants (tPAH, $\mathrm{tPCB}$ and $\mathrm{tDDT}$ ) were used. Data on concentration levels adsorbed to pellets in the literature for tPCB and tDDT. Costa Nova beach in the north of Portugal registered $27 \mathrm{ng} \mathrm{g}^{-1}$ and $1.69 \mathrm{ng} \mathrm{g}^{-1}$ for tDDT (Ogata et al., 2009). Results for state of Washington and state of California have values of $\mathrm{PCB}$ ranging from 32 to $605 \mathrm{ng} \mathrm{g}^{-1}$ and ranging from 5.09 to $267 \mathrm{ng} \mathrm{g}^{-1}$ for tDDT. Concentration values for islands (Hawai'i, Canary and Barbados), had concentrations of $\mathrm{tPCB}$ ranging from 0.1 to $4.1 \mathrm{ng} \mathrm{g}^{-1}$ and ranging from 0.7 to $4.1 \mathrm{ng} \mathrm{g}^{-1}$ for tDDT (Heskett et al. 2012). All values for $\mathrm{PCB}$ concentrations were determined by the sum of 13 PCB congeners. Values for Cresmina beach and Fonte da Telha beach are also available (Frias et al., 2011), with tPBC ranging from 6.9 to $36.3 \mathrm{ng} \mathrm{g}^{-1}$ (sum of $18 \mathrm{PCB}$ congeners), tDDT ranging from 0.61 to $4.43 \mathrm{ng} \mathrm{g}^{-1}$ and $\mathrm{tPAH}$ ranging from 75 to $1350 \mathrm{ng} \mathrm{g}^{-1}$.

By comparing results with literature, $\mathrm{tDDT}$ concentrations for this study are higher and $\mathrm{tPCB}$ are lower when compared to the result in Ogata et al. (2009) for Portugal. When compared to the Washington and California concentrations in pellets to our results, lower concentrations can be found in Alcobaça. In the case of California, that may be explained by the population and industrial activities in the coastal area. For the case of Washington, intense agriculture may be the reason for high concentrations of DDT. Compared to Heskett et al. (2012), results are in the same concentration range, which are not that high considering that pellets were obtained in remote islands like Hawai'i. When compared to Cresmina and Fonte da Telha beaches in Portugal, results approximately in the same concentration range, except for white pellets in Alcobaça with showed lower concentrations of $\mathrm{tPCB}$ and $\mathrm{tPAH}$.

Higher concentrations of PBTC were found for phenantrene $(\mathrm{P})$ and benzo(a)pyrene $(\mathrm{BaP})$, which are potential carcinogenic agents. PCB congeners 153, 180 and 187 were the ones with higher concentrations, which also have ecotoxicologic effects in animals (Magnusso et al., 2006) DDT is one of the strongest examples of persistence, because this pesticide was banned in Europe in the 1970's and in Portugal, in 1988 (Decreto-Lei n. 347/88 and Portaria n. 660/88), but traces are still found in the environment 
(Takada et al., 2005). The values found in our study pose no concern, but nonetheless awareness must be raised to the possibility of toxic effects that even small concentrations of PBTC adsorbed to plastics may have on marine species and the environment.

Sorption of different contaminants varies with polymer type (e. g. polyethylene, polypropylene) (Rochman et al., 2013), and so it would be interesting to conduct PBTC analysis having into account polymer composition of the pellets, which was not considered in this study and limits further interpretation.

Collaboration with local schools in Alcobaça municipality was a valuable experience for the all stakeholders involved (the municipality, teachers, scientists, high school students), not only for the importance of data gathered but also for the direct science outreach and awareness raising on the presence of plastic marine debris on the beaches, persistence of pollutants, their effects on marine organisms and the need to reduce single-use plastic items in our daily activities. Engaging in local beach clean-up activities such as these is a way to inform citizens in a pedagogic and educative way of how to contribute to environmental management processes.

\section{CONCLUDING REMARKS}

In this study, PV was the most contaminated beach of all three beaches sampled, having both the highest number and mass of items $\mathrm{m}^{-2}$. No concerning concentrations of PBTC were found for Alcobaça municipality beaches, when compared with other beaches in Portugal and worldwide. White, aged and coloured pellets showed higher values of tDDT when compared to the data from 2009 and 2012, confirming the high persistence of this pesticide in the environment.

Feedback from participants involved in the beach cleanup was positive and lessons were learned about how excessive daily consumption and disposal of plastic and other litter (plastic, paper, metal), may lead to waste management problems. Beach clean-up activities are one of the many possible solutions to tackle plastic marine debris in coastal waters and in the oceans and contribute to increase public participation in environmental management processes.

\section{ACKNOWLEDGMENTS}

We would kindly like to acknowledge Maria Guilhermina Galego, for providing us the possibility to work close collaboration with the Alcobaça municipality through Geota's Project - Coastwatch, and Sofia Quaresma, for her enthusiastic support and cooperation, and without whom this work would not have been possible. We would like to acknowledge as well the teachers and students of Benedita's high school, namely the students Alice Belo and Mara Rebelo for their help in Gralha beach litter collection. We would like also to thank Isabelina Santos, Cristina Micaelo and Ana Maria Ferreira from Instituto Português do Mar e da Atmosfera (IPMA) for POP analysis in plastic pellets. Finally, we would like to acknowledge Fundação para a Ciência e Tecnologia for their financial support through the project 'Microplastics and persistent pollutants - a double threat to marine life (POIZON)' reference PTDC/ MAR/102677/2008.

\section{REFERENCES}

Andrady, A.L. (2011) - Microplastics in the marine environment. Marine Pollution Bulletin, 62(8):15961605. DOI: 10.1016/j.marpolbul.2011.05.030

Arthur, C.; Baker, J.; Bamford, H. (eds.) (2008) - Proceedings of the International Research Workshop on the Occurrence, Effects and Fate of Micro-plastic Marine Debris. NOAA Technical Memorandum NOS-OR\&R-30. Silver Spring, MD, U.S.A. Available in: http://marinedebris.noaa.gov/ projects/pdfs/Microplastics.pdf

Barnes, D.K.A.; Galgani, F.; Thompson, R.C.; Barlaz, M.A. (2009) - Accumulation and fragmentation of plastic debris in global environments. Philosophical Transactions of Royal Society London, 364(1526):1985-1998. DOI: 10.1098/rstb.2008.0205

Bodin, N.; Abarnou, A.; Fraisse, D.; Defour, S.; Loizeay, V.; Le Guellec, A.M.; Philippon, X. (2007) - PCB, $\mathrm{PCDD} / \mathrm{F}$ and PBDE levels and profiles in crustaceans from the coastal waters of Brittany and Normandy (France). Marine Pollution Bulletin, 54(6):657-688. DOI: 10.1016/j.marpolbul.2007.01.018

Bravo, M.; Gallardo, M.A.; Luna-Jorquera, G.; Núñez, P.; Vásquez, N.; Thiel, M. (2009) - Anthropogenic debris on beaches in the SE Pacific (Chile): Results from a national survey supported by volunteers. Marine Pollution Bulletin, 58(11):1718-1726. DOI: 10.1016/j. marpolbul.2009.06.017

Browne, M.A.; Dissanayake, A.; Galloway, T.; Thompson, R.C. (2008) - Ingested Microscopic Plastic Translocates to the Circulatory System of the Mussel, Mytilus edulis (L.). Environmental Science and Technology, 42(13):50265031. DOI: 10.1021/es800249a

Cole, M.; Lindeque, P.; Halsband, C.; Galloway, T.S. (2011) Microplastics as contaminants in the marine environment: A review. Marine Pollution Bulletin, 62(12):2588-2597. DOI: $10.1016 /$ j.marpolbul.2011.09.025

Corcoran, P.L.; Biesinger, M.C.; Grifi, M. (2009) - Plastics and beaches: Adegrading relationship. Marine Pollution Bulletin, 58(1):80-84. DOI: 10.1016/j.marpolbul.2008.08.022

Costa, M.F.; Ivar do Sul, J.A.; Silva, J.S.; Cavalcanti, S.; Araújo, M.C.; Spengler, Â.; Tourinho, P.S. (2010) - On the importance of size of plastic fragments and pellets on the strandline: a snapshot of a Brazilian beach. Environmental Monitoring and Assessment, 168:299-304. DOI: $10.1007 /$ s10661-009-1113-4.

Crimmins, B.S.; Brown, P.D.; Kelso, D.P.; Foster, G.D. (2002) - Bioaccumulation of PCBs in Aquatic Biota from a Tidal Freshwater Marsh Ecosystem. Archives of Environmental Contamination and Toxicology, 42(4):396404. DOI: 10.1007/s00244-001-0047-9

Debrot, D.O.; Tiel, A.B.; Bradshaw, J.E. (1999) - Beach debris in Curaçao. Marine Pollution Bulletin, 38(9):795801. DOI: 10.1016/S0025-326X(99)00043-0.

Derraik, J.G.B. (2002) - The pollution of the marine environment by plastic debris: a review. Marine Pollution Bulletin, 44(9):842-852. DOI: 10.1016/S0025326X(02)00220-5.

Furness, B.L. (1983) - Plastic particles in three procellariiform seabirds from the Benguela Current, South Africa. Marine 
Pollution Bulletin, 14(8):307-308. DOI: 10.1016/0025326X(83)90541-6

Franeker, J.A.; Blaize, C.; Danielsen, J.; Fairclough, K.; Gollan, J.; Guse, N.; Hansen, P.; Heubeck, M.; Jensen, J.; Guillou, G.L.; Olsen, B.; Olsen, K.; Pedersen, J.; Stienen, E.W.M.; Turner, D.M. (2011) - Monitoring plastic ingestion by the northern fulmar Fulmarus glacialis in the North Sea. Environmental Pollution, 159(10):26092615. DOI: 10.1016/j.envpol.2011.06.008

Frias, J.P.G.L.; Sobral, P.; Ferreira, A.M. (2010) - Organic pollutants in microplastics from two beaches of the Portuguese coast. Marine Pollution Bulletin, 60(11):19881992. DOI: 10.1016/j.marpolbul.2010.07.030

Frias, J.P.G.L.; Martins, J.; Sobral, P. (2011) - Research in plastic marine debris in mainland Portugal. Journal of Integrated Coastal Zone Management, 11(1):145-148. DOI: $10.5894 /$ rgci267

Bowmer, T.; Kershaw, P.J. (eds.) (2010) - Proceedings of the GESAMP International Workshop on plastic particles as a vector in transporting persistent, bio-accumulating and toxic substances in the oceans. Pre-publication copy. 68p., GESAMP Reports \& Studies No. 82, IMO/FAO/ UNESCO-IOC/UNIDO/ WMO/IAEA/UN/UNEP Joint Group of Experts on the Scientific Aspects of Marine Environmental Protection (GESAMP), Londo, U.K. Available in http://www.gesamp.org/data/gesamp/ files/media/Publications/Reports_and_studies_82/ gallery_1510/object_1670_large.pdf

Gregory, M.R.; Andrady, A.L. (2003) - Plastics in the Marine Environment. In: A. L. Andrady (ed.), Plastics and the Environment, pp.389-402, Wiley Interscience, New York, NY, U.S.A. ISBN: 0471095206.

Galgani, F.; Fleet, D.; Van Franeker, J.; Katsanevakis, S.; Maes, T.; Moaut, J.; Oosterbaan, I.; Poitou, I.; Hanke, G.; Thompson, R.; Amato, E.; Birkun, A.; Janssen, C. (2010) - Marine Strategy framework Directive Task Group 10 Report Marine litter, 48p., Office for Official Publications of the European Communities, Luxembourg. ISBN 97892-79-15653-3. Available at http://publications.jrc. ec.europa.eu/repository/bitstream/111111111/13625/1/ tg10final.pdf

Heskett, M.; Takada, H.; Yamashita, R.; Yuyama, M.; Ito, M.; Geok, Y.B.; Ogata, Y.; Kwan, C.; Heckhausen, A.; Taylor, H.; Powell, T.; Morishige, C.; Young, D.; Patterson, H.; Robertson, B.; Bailey, E.; Mermoz,J.(2012)-Measurement of persistent organic pollutants (POPs) in plastic resin pellets from remote islands: Toward establishment of background concentrations for International Pellet Watch. Marine Pollution Bulletin, 64(2):445-448. DOI: 10.1016/j.marpolbul.2011.11.004

Hijonosa, I.A.; Thiel, M. (2009) - Floating marine debris in fjords, gulfs and channels of southern Chile. Marine Pollution Bulletin, 59(3):341-350. DOI: 10.1016/j. marpolbul.2008.10.020

Ivar do Sul, J.A.; Costa, M.F. (2007) - Marine debris review for Latin America and the wider Caribbean region: from the 1970s until now, and where do we go from here? Marine Pollution Bulletin, 54(8):1087-1104. DOI: 10.1016/j. marpolbul.2007.05.004
Laist, D.W. (1987) - Overview of the biological effects of lost and discarded plastic debris in the marine environment. Marine Pollution Bulletin, 18(6-sup.B):319-326. DOI: 10.1016/S0025-326X(87)80019-X

Laist, D.W. (1997) - Impacts of marine debris: entanglement of marine life in marine debris including a comprehensive list of species with entanglement and ingestion records. In: J.M. Coe \& D.B. Rogers (eds.), Marine Debris. Sources, Impacts, Solutions, pp.99-140, Springer-Verlag, New York, NY, U.S.A.

Law, K.L.; Moret-Ferguson, S.; Maximenko, N.A.; Proskurowski, G.; Peacock, E.E.; Hafner, J.; and Reddy, C.M. (2010) - Plastic Accumulation in the North Atlantic Subtropical Gyre. Science, 329(5996):1185-1188. DOI: $10.1126 /$ science. 1192321

Luís, I.P.; Spínola, H. (2010) - The influence of a voluntary fee in the consumption of plastic bags on supermarkets from Madeira Island (Portugal). Journal of Environmental Planning and Management, 53(7):883-889. DOI: 10.1080/09640568.2010.490054

Magnusson, K.; Ekelund, R.; Grabic, R.; Bergqvist, 2006. Bioaccumulation of PCB congeners in marine benthic infauna. Marine Environmental Research, 61(4):379- 395. DOI: $10.1016 /$ j.marenvres.2005.11.004

Martins, J.; Sobral, P. (2011) - Plastic marine debris on the Portuguese coastline: A matter of size? Marine Pollution Bulletin, 62(12):2649-265. DOI: 10.1016/j. marpolbul.2011.09.028

Martins, M.; Ferreira, A.M.; Vale, C. (2008) - The influence of Sarcocornia fruticosa on retention of PAHs in salt marsh sediments (Sado estuary, Portugal). Chemosphere, 71(8):1599-1606. DOI: 10.1016/j. chemosphere.2007.10.054

Martins, M.; Costa, P. M.; Raimundo, J.; Vale, C., Ferreira, A.M.; Costa, M. H. (2012) - Impact of remobilized contaminantsin Mytilus edulis during dredging operations in a harbour area: Bioaccumulation and biomarker responses. Ecotoxicology and Environmental Safety, 85:96103. DOI: 10.1016/j.ecoenv.2012.08.008.

Mato, Y.; Isobe, T.; Takada, H.; Ohtake, C.; Kaminuma, T. (2001) - Plastic resin pellets as a transport medium for toxic chemicals in the marine environment. Environmental Science and Technology, 35(2):318-324. DOI: 10.1021/ es0010498

Moore, S.L.; Gregorio, D.; Carreon, M.; Weisberg, S.B. (2001a) - Composition and distribution of beach debris in orange county, California. Marine Pollution Bulletin, 42(3),241-245. DOI: 10.1016/S0025326X(00)00148-X

Moore, C.J.; Moore, S.L.; Leecaster, M.K.; Weisberg, S. B. (2001b) - A comparison of plastic and plankton in the North Pacific Central Gyre. Marine Pollution Bulletin, 42(12):1297-1300. DOI: 10.1016/S0025326X(01)00114-X

Moore, C.J.; Moore, S.L.; Weisberg, S.B.; Lattin, G.W.; Zellers, A.F. (2002) - A comparison of neustonic plastic and zooplankton abundance in Southern California's coastal waters. Marine Pollution Bulletin, 44(10):10351038. DOI: 10.1016/S0025-326X(02)00150-9 
Moore, C.J. (2008) - Synthetic polymers in the marine environment: A rapidly increasing, long-term threat. Environmental Research, 108(2):131-139. DOI: 10.1016/j.envres.2008.07.025

Ogata, Y.; Takada, H.; Mizukawa, K.; Hirai, H.; Iwasa, S.; Endo, S.; Mato, Y.; Saha, M.; Okuda, K.; Nakashima, A.; Murakami, M.; Zurcher, N.; Booyatumanondo, R.; Zakaria, M.P.; Dung, L.Q.; Gordon, M.; Miguez, C.; Suzuki, S.; Moore, C.; Karapanagioti, H.K.; Weets, S.; McClurg, T.; Smith, W.; Valkenburg, M.V.; Lang, J. S.; Lang, R.C.; Laursen, D.; Danner, B.; Stewardson N.; Thompson, R.C. (2009) - International Pellet Watch: Global monitoring of persistent organic pollutants (POP) in coastal waters. 1. Initial phase data on PCBs, DDTs, and HCHs. Marine Pollution Bulletin, 58(10):14371446. DOI: 10.1016/j.marpolbul.2009.06.014

Page, B.; McKenzie, J. (2004) - Entanglement of Australian sea lions and New Zealand fur seals in lost fishing gear and other marine debris before and after Government and industry attempts to reduce the problem. Marine Pollution Bulletin, 49(1-2):33-42. DOI: 10.1016/j. marpolbul.2004.01.006

Plastics Europe (2012) - Plastics - the Facts 2012- An analysis of European plastics production, demand and recovery for 2011. 35p., PlasticsEurope, Brussels, Belgium. Available in http://www.plasticseurope.org/Document/plastics-thefacts-2012.aspx?Page=DOCUMENT\&FolID $=2$

Pichel, W.G.; Churnside,J.; Veenstra, T.; Foley, D.; Friedman, K.; Brainard, R..; Nicoll, J.; Zheng, Q.; ClementeColón, P. (2007) - Marine debris collects within the North Pacific subtropical convergence zone. Marine Pollution Bulletin, 54(10):1207-121. DOI: 10.1016/j. marpolbul.2007.04.010
Rochman, C.M.; Hoh, E.; Hentschel, B.T.; Kaye, S. (2013) - Long-term field measurement of Sorption of organic contaminants to five types of plastic pellets: implications for plastic marine debris. Environmental Science and Technology, 47(3):1646-1654. DOI: 10.1021/ es303700s.

Takada, H.; Mato, Y.; Endo, S.; Yamashita, R.; Zakaria, M.P. (2005) - Pellet Watch: Global Monitoring of Persistent Organic Pollutants (POPs) using Beached Plastic Resin Pellets. In: C. Moore \& S. David (eds.), The Plastic Debris Rivers to Sea Conference: Focusing on the Land-Based Sources of Marine Debris, Redondo Beach, CA, U.S.A.

Teuten, E.L.; Rowland, S.J.; Galloway, T.S.; Thompson, R.C. (2007) - Potential for Plastics to Transport Hydrophobic Contaminants. Environmental Science and Technology, 41(22):7759-7764. DOI: 10.1021/es07173

Thiel, M.; Hinojosa, I.; Vásquez, N.; Macaya, E. (2003) Floating marine debris in coastal waters of the SE-Pacific (Chile). Marine Pollution Bulletin,46(2):224-231. DOI: 10.1016/S0025-326X(02)00365-X

Thompson, R.C.; Olsen, Y.; Mitchell, R.P.; Davis, A.; Rowland, S.J.; John, A.W.G.; McGonigle, D.; Russell, A.E. (2004) - Lost at Sea: where is all the plastic? Science, 304(5672):838. DOI: 10.1126/science.1094559

Vlieststra, L.S.; Parga, J.A. (2002) - Long-term changes in the type, but not amount, of ingested plastic particles in short-tailed shearwaters in the southeastern Bering Sea. Marine Pollution Bulletin, 44(9):945-955. DOI: 10.1016/S0025-326X(02)00130-3 